\title{
A Vajdaságot érintő migráció és annak történeti előzményei
}

\author{
The migration concerning Vojvodina and its historical \\ preliminaries
}

\section{TÁTRAI PATRIK, KOCSIS KÁROLY, GÁBRITY MOLNÁR IRÉN, TAKÁCS ZOLTÁN}

KULCSSZAVAK: belföldi vándorlás, nemzetközi vándorlás, etnikai migráció, menekültek, Szerbia

ABSZTRAKT: Tanulmányunkban a Vajdaságot érintő főbb belföldi és nemzetközi migrációs folyamatokat, valamint ezek történeti előzményeit mutatjuk be. Kiemelt szerepet kap az elmúlt két évtizedben, azaz a délszláv polgárháború kirobbanása óta lezajlott migrációs hullámok ismertetése, valamint területileg a Vajdaságból Magyarországra irányuló vándorlás. Az elmúlt évszázad Vajdaságba, illetve onnan Magyarország mai területére irányuló migrációs folyamatait vizsgálva megállapítható, hogy a vándorlások szempontjából alapvetően kétféle időszakot határolhatunk le: egyrészt a háborús időszakokat, amikor az államhatárok változása miatt tömeges (kényszer)migráció bontakozott ki; másrészt a békeidőt, amikor a vándorlási folyamatok jellemzően önkéntesnek tekinthetők, és a migráció gazdasági meghatározottsága került előtérbe. Utóbbi időszakokban a fő migrációs irányok követték a fejlettségi különbségeket. Ugyanakkor a vizsgált migráció legfőbb jellemzője - időszaktól függetlenül -, hogy az etnicitás kulcsfontosságú szerepet játszik benne.

KEYWORDS: domestic migration, international migration, ethnic migration, refugees, Serbia

ABSTRACT: The study aims to outline the migration that affected the Vojvodina in the last two decades and to examine the historical roots of contemporary migration. It overviews both the domestic and the international migration waves, with special emphasis on the migration from Vojvodina to Hungary. Our objectives are to present the main migration waves and their background in political, economic and ethnic terms.

The migratory processes concerning Vojvodina should be divided according to different periods. These migration periods strongly depend on the (geo)political circumstances of the period in question, since the most significant (forced) migration waves were triggered by wars and by the change of political systems and state borders. During peaceful periods, mostly economic inequalities and regional disparities influence voluntary migration. Thus most of the migrants have followed the undeveloped-developed (or periphery-centre) direction, which has hardly changed in the last century. This phenomenon fits the global migration system as well, since the direction of migration is generally from East to West (e.g. guest workers) or from South to North (e.g. refugees of the Yugoslav wars to Vojvodina; or Vojvodina Hungarians to Hungary).

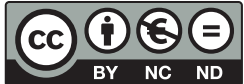


Beside the political and economic factors, ethnicity plays the most important role in the migration examined in this study. According to our perception, every migratory process in which ethnicity represents symbolic, cultural or social capital is considered to be ethnic migration (e.g. the forced migrations generated by the changes of borders, the flight of Serb refugees to Serbia and the resettlement of Vojvodina Hungarians in Hungary). However, we would emphasize that ethnic push factors (e.g. ethnic tensions, discrimination) as well as economic inequalities and development gaps also contribute to ethnic migration.

\section{Bevezetés}

Jelen tanulmány a Vajdaságot az elmúlt két évtizedben érintő migrációs folyamatok, valamint a közelmúltbéli vándorlások történeti gyökereinek bemutatására vállalkozik. Dolgozatunk - különböző szerzők publikációira építve - összefoglaló áttekintést nyújt a Vajdaságot érintő belföldi és nemzetközi migrációról, egyaránt bemutatva a be- és kivándorlási hullámokat. Célunk a főbb vándorlási folyamatok, valamint a migrációt befolyásoló fontosabb politikai, gazdasági és etnikai tényezők korszakonkénti bemutatása.

A Vajdaság migrációs folyamatai jellegzetes korszakokra bonthatók. A migrációs periódusok erőteljesen függenek az adott korszak (geo)politikai viszonyaitól, hiszen a legnagyobb volumenű (kényszer)migrációk háborúkhoz, illetve államhatalom-változásokhoz köthetők. Békésebb időszakokban elsősorban a gazdasági, fejlettségbeli különbségek jelentik a migráció mozgatórugóját.

A viszonylag egyértelmű politikai és gazdasági tényezők mellett az etnicitás migrációban betöltött szerepe bonyolultabb. Az etnikai migráció értelmezésére ha nem is a Vajdaságra fókuszálva - több tanulmány is kísérletet tett. Feischmidt és Zakariás (2010), valamint Gödri (2010a) az etnikai migráció három - akár egyszerre jelen levő - alaptípusát különíti el. Ezek - leegyszerüsítve - (1) az anyaország kulturális vonzása; (2) gazdasági indíttatású migráció, melyben „a nyelvi és/vagy kulturális azonosság (...) úgy játszik szerepet, mint szimbolikus vagy társadalmi tőke, amely csökkenti a migráció és az integráció költségeit" (Feischmidt, Zakariás 2010, 152.); továbbá (3) etnikai jellegű taszító tényezők (etnikai konfliktus, diszkrimináció és a kisebbségi státus elutasítása). Térségünkben utóbbira kiváló példát nyújtanak a nagy geopolitikai változások, amikor a határok újrarajzolása, a nemzetállam-építés és az etnikai homogenizációra való törekvés jelentősen elösegítette a mobilitást. Értelmezésünkben minden olyan vándorlási folyamat, amelyben az etnicitásnak mint szimbolikus, kulturális és társadalmi tőkének szabályozó szerepe van, etnikai migrációnak tekinthető (vö. Brubaker 1998). Jól látható tehát, hogy a fenti értelmezési keretek (kényszermigráció, gazdasági migráció, etnikai migráció) változó súllyal alkalmazhatók az egyes vándorlási korszakokra; néha egyszerre hatottak, néha az egyik hatása markánsabban jelentkezett. Mégis ki kell emelni, hogy a politikai (háborús vagy kényszer-) és a gazdasági (békés vagy 
önkéntes) migrációkkal szemben az etnicitás migrációban betöltött szerepe korszakokon átívelő és minden időszakban meghatározó.

\section{Történeti áttekintés}

\section{8 elött}

A történelmi Dél-Magyarország (Délvidék), a mai Észak-Szerbia (Vajdaság) KözépEurópa határvidékén, a Közel-Keletet és Nyugat-Európát összekötő Isztambul-Belgrád-Bécs-foút mentén, a Balkán kapujában mindig a „népek országútjának”, forgalmi csomópontnak számított. Így a Duna, Tisza és Száva folyók találkozásánál fekvő vidék népességének arculatát az évezredes migrációk folytonosan változtatták.

A mai Vajdaság - az iszlám térhódításának, az oszmán (török) hódoltságnak elsőként áldozatul esett magyarországi terület - a 16. század első és a 17. század utolsó évtizedeiben, a hatalomváltást eredményező hadjáratok során elnéptelenedett, középkori magyar lakosságát elveszítette. A török végleges kiüzése, a Bánság visszafoglalása után ez a szinte lakatlan dél-alföldi, az ország legértékesebb termőföldjeivel rendelkező - új nagybirtokosok és a kamara kezébe került terület demográfiai vákuumként vonzotta Magyarország és a külföld lakóit. A 18. századi, alapvetően agrárjellegű migráció jellemzően szervezett kolonizáció volt, melyből jelentős részt képviselt a külföldről történő bevándorlás (főként németek betelepítése). Ugyanakkor számottevő volt a környező területek (pl. magyar, szerb, román) népességének spontán bevándorlása is. Az időszak politikai indíttatású kényszermigrációit főként a szerbeknek az osztrák-török háborúkat követő beáramlásai jelentették (1716-1718, 1737-1739, 1788-1789).

A 19. század második felében, alapvetően az osztrák-magyar dualizmus idején rendkívül megnövelte a népesség térbeli mobilitását az 1848-as jobbágyfelszabadítás és következményei (pl. a volt jobbágyok szabad költözködése), a közlekedési helyzet javulása (rendkívül sürü délvidéki vasútvonal-hálózat létrejötte), a jelentős népességtöbbletet eredményező, 1870-es évektől kibontakozó demográfiai átmenet, ${ }^{1}$ a délvidéki nagybirtok-parcellázások és nem utolsósorban az itteni katonai határőrvidék felszámolása, polgárosítása $(1873,1881)$. A volt határőrvidéki területeken (pl. a Szerémségben, a Sajkásvidéken) a hatalmas, addig alig, illetve extenzíven művelt tájak mágnesként vonzották a földre éhes embereket. A nagyarányú kereslet a korábbi szerb határőrök körében valóságos birtokeladási lázat váltott ki, ami a földet egyre olcsóbbá tette. Ez az „olcsóság”, valamint a Dunától északra fekvő területeken a túlnépesedés, a hasonló természeti, agrártáji környezet és az ismert mezőgazdasági termelési módszerek alkalmazásának lehetősége a szegény, földéhes bácskai parasztok valóságos beözönlését eredményezte a Szerémségbe (általában a Dráva, Duna és Száva közötti, Szlavóniának ne- 
vezett területre). A 19. és 20. század fordulójára - a hazai kapitalizmus és urbanizáció kibontakozásával párhuzamosan - a belföldi migráció motivációi között egyre nagyobb szerepet játszott a nagyobb városokban tömörülő, nem agrárjellegü (fóként ipari) munkahelyek vonzereje is. A dualizmus kori belső migráció ${ }^{2}$ mérete és iránya jól számszerűsíthető az 1900. és 1910. évi népszámlálások (születési és lakóhelyet nyilvántartó) adataiban. ${ }^{3}$ A vizsgált három megye közül a nagy agrártömegeket vonzó Szerém vármegyében volt a legalacsonyabb a szülőhelyükön összeírtak aránya (1910-ben 65,7\%), míg a nagy tömegeket kibocsátó Bács-Bodrogban a legmagasabb (77,7\%). A születési és lakóhelyek egybevetése alapján számított népességcsere egyenlege szerint a bácskai és bánsági területek népességvesztesége a legnagyobbak közé tartozott az országban (Beluszky 2004). Az itteni, megyehatárt átlépő agrárnépesség-felesleg többsége a Szerémségbe távozott, míg a városokba költöző bácskaiak és bánságiak zömét Budapest és a közeli regionális központok (Temesvár és Szeged) vonzották.

Az Osztrák-Magyar Monarchia határát átlépő migrációról megállapítható, hogy a 19. század végén főként a későbbi magyarországi földvásárlás, paraszti tőkefelhalmozás céljából egyre nagyobb tömegek vándoroltak (többnyire ideiglenes szándékkal) külföldre, alapvetően Amerikába. 1899 és 1913 között a három délvidéki megye (jórészt Torontál) területéről kb. 150 ezren vándoroltak ki, 53\%uk német, 18\%-uk szerb, 10\%-uk magyar anyanyelvü volt (A Magyar Szent Korona... 1918). A németek (a délvidéki népességen belüli arányukhoz viszonyított) tetemes fölülreprezentáltsága a kivándorlók körében elsősorban sajátos (az elsőszülött fiút kedvezményező) örökösödési szokásaikból eredő tőkefelhalmozási terveikkel állt összefüggésben. A külföldről (főként a Monarchián kívülről) érkező bevándorlás a dualizmus idején mindvégig alacsony szintű (az országos átlag alatti) maradt, még a Szerbiával szomszédos Szerémségben is. ${ }^{4}$

\section{8-1948}

Az 1918 végi magyar-szerb államhatalom-váltást és az új államhatárok megvonását követően a délvidéki migrációs folyamatok kiváltó oka, iránya és tendenciája alapvetően megváltozott. Az idegen uralom elől a magyar állami alkalmazottak, nagybirtokosok, értelmiségiek jelentős része Magyarország maradék területére távozott (kb. 33 ezer fö), helyükre elsősorban szerb adminisztráció érkezett Szerbiából (mintegy 16 ezer fö) (Kocsis 1996). Ebben az időben több ezer bánsági román költözött át a határ román oldalára. A délszláv nemzeti célokat is szolgáló agrárreform keretében pedig 45 ezer szerb és 3 ezer magyarországi bunyevác települt a Vajdaságba 1918-1931 között (Kocsis 1996). ${ }^{5}$

A vizsgált időszakban az államhatárok és a (nemzet)politikai szempontok változása miatt az addigi migrációs útvonalak jelentős része megszakadt, ugyanakkor újak nyíltak: a korábbi legjelentősebb belföldi vonzásközpontok (Budapest, Szeged, Temesvár) „külföldre kerültek”, a Vajdaság mai területe az 
újonnan létrehozott Szerb-Horvát-Szlovén Királyság részeként viszont nyitottá vált a sokkal fejletlenebb balkáni területek felé. A nemzetközi migráció, a gazdasági és politikai okokkal összefüggő kivándorlás (főként a tengerentúlra) továbbra is jelentős maradt. ${ }^{6}$ Az agrárreformból kimaradt és a nagybirtokok kisajátításával munkanélkülivé vált földnélküli magyar népesség jelentős része pedig a városokba, fóként az új tartományi székhelyre (Újvidékre), ${ }^{7}$ kisebb részben a fövárosba (Belgrádba) költözött (Gábrity 2001, Kocsis 1996).

A 2. világháború időszakát újabb határváltozások, az ezeket követő kényszermigráció, valamint kölcsönös etnikai tisztogatások jellemezték. 1941 áprilisában Magyarország visszaszerezte Bácskát, Horvátország a Szerémséget, míg a Vajdaság bánsági része elvileg szerb - gyakorlatilag német - közigazgatás alatt maradt. 1941-ben a magyar hatóságok mintegy 12 ezer betelepült szerbet, zsidót és politikailag gyanús személyt internáltak. A magyar fennhatóság több mint három éve alatt közel 25 ezer fö került át Szerbiába menekültként vagy visszatoloncoltként (A. Sajti 1987; Milošević 1981). ${ }^{8}$ A kiürített szerb telepesfalvakba 13,4 ezer bukovinai és moldvai, valamint 2,5 ezer egyéb magyart (vitézi családok, boszniai magyarok) telepítettek. Az agrártelepítések mellett mintegy 20 ezer fönyi magyarországi (közalkalmazott, rendfenntartó) érkezett a visszafoglalt Bácskába (Kocsis 1996). Jól látható tehát, hogy a határváltozást követő, 1941-1944 közötti periódusban a magyar nemzetépítés ugyanazokat az eszközöket vette igénybe, mint 1918 után a szerb. Ennek megfelelően az időszak migrációs eseményei is ugyanazt a forgatókönyvet követték, mint húsz évvel korábban, csak fordított előjellel.

A kényszermigráció 1944-től immár több százezer lakost érintett. 1944 áprilisában kb. 16 ezer zsidó származású személyt deportáltak Németországba, majd - a front közeledtével, 1944 szeptemberében, októberében - megkezdödött a magyar hatóságok, az 1941 után betelepült magyarok, valamint a vajdasági németek evakuálása (Kocsis 1996; Mirnić 1974).

1944-1947 között mintegy 65 ezer fö (többnyire magyar) menekült települt át az időközben, 1945 augusztusában újra létrejött Jugoszláviából a mai Magyarország területére (Stark 2001). Eközben a helyben maradt németeket és a hadköteles magyar férfiak egy részét megtizedelték, internálótáborokba gyüjtötték. A táborokat túlélő német népességet később Németországba deportálták. ${ }^{9}$ A kitelepített, elmenekült németek és magyarok helyére 1945-1948 között 226 ezer - nagyságrend szerint - szerb, montenegrói, macedón, horvát, szlovén lakost telepítettek a második jugoszláv földreform keretében (Gaćeša 1984).

Összességében az 1918-1948 közötti időszakot a háborús migrációk (menekülések, kiutasítások, deportálások) és az államhatalom-váltás után azonnal meginduló állami telepítések jellemezték. A migránsok etnikai összetételét és a vándorlási útvonalakat elsősorban az határozta meg, hogy a vizsgált terület melyik államhoz tartozott. 


\section{8-1991}

A földreformhoz kapcsolódó állami telepítések 1948-ban befejeződtek, ezután a migráció szempontjából (is) új korszak vette kezdetét. Bár a titói Jugoszláviában nem szűnt meg a (nemzet)politikai szempontú „irányított”, belföldi migráció (Mirnics 2001), meghatározóvá vált az önkéntes, gazdasági indíttatású vándorlás. Ebben szerepet játszott a Vajdaság agrárpotenciálja (falvakból falvakba vándorlás - akár régiók között is), majd később az iparosítás (falvakból városokba vándorlás), továbbá a beruházások egyenlőtlen területi eloszlása (régiók közötti vándorlás) (Kocsis 1985, 1996). A területi mobilitás ezen időszakra jellemző értékei meghaladták a korábbi évszázadét: az 1991-es népszámlálás szerint a Vajdaság lakosságának 45\%-a (915 ezer fö) nem azon a településen élt, ahol született. ${ }^{10}$ Ezen belül a Vajdaságon kívülről bevándoroltak aránya 20\% (400 ezer fö) körül mozgott, döntő többségük (75-77\%) szerb volt (Mirnics 2001).

A korszak kezdetén (1948-1953 között) a kivándorlás volt jellemző: az 1945-1948 között betelepített kolonisták közel tizede ugyanis - elsősorban a szülőföldjüktől eltérő környezet, gazdálkodás, illetve a fejlettségi különbségek miatt nem boldogult a Vajdaságban és visszatért származási helyére (Đurđev 1995). A telepesek mellett a kivándorlók közt találjuk a németek azon csoportjait is, akik ekkor szabadultak a koncentrációs táborokból.

1953 után a Vajdaságba érkező migránsok száma ismét meghaladta az elvándorlókét; a betelepülők többsége agrármigránsnak tekinthető (Đurđev 1995). A bevándorlás forrásterületei alapvetően Közép-Szerbia, ${ }^{11}$ valamint Bosznia-Hercegovina és Horvátország periférikus hegyvidéki, szerblakta területei voltak. Az 1960-as évektől a legtöbben már Boszniából érkeztek, a Horvátországból bevándorlók száma jelentősen csökkent. A kibocsátó területek változása azt mutatja, hogy a Vajdaság - mint dominánsan agrárterület - az 1960-as évektől fokozatosan vesztett vonzerejéből, szemben a magasabb életszínvonalat biztosító iparosodottabb régiókkal (pl. Közép-Szerbia és főként Belgrád), valamint az 1970-es évektől a horvát tengerparttal (Đurđev 1995; Kocsis 1985).

A tényt, hogy elsősorban szerb lakosság települt be, két tényező indokolja. Egyrészt a gazdasági faktor, hiszen a Vajdaság jóval fejlettebbnek számított a kibocsátó területeknél. Másrészt a kapcsolati hálózatok is kiemelkedően fontos szerepet játszottak a migrációban (Erőss, Filep, Rácz, Tátrai, Váradi, Wastl-Walter 2011; Gödri 2010a; Tilly 2001). Az 1945-1948 között a Vajdaságba betelepített népesség biztosította a migrációhoz szükséges információkat, ismereteket az otthon maradt családtagoknak, barátoknak, ismerősöknek.

Az elvándorlás területi mintázatai jelentősen eltérnek a bevándorlásétól. A szocializmus időszakában a Vajdaságból belföldre elvándorlók kétharmada Közép-Szerbiába (alapvetően a fővárosba) költözött, számuk folyamatosan emelkedett. Népszerű célpont volt Horvátország is, ugyanakkor Bosznia-Hercegovina részesedése az elvándorlásból jóval alacsonyabb volt, mint az onnan a Vajdaságba érkező bevándorlás aránya. Az így felállított belföldi migrációs mérlegből az derül 
ki, hogy 1961 és 1981 között a Vajdaság ugyan befogadó terület volt, de bevándorlási többlete egyre csökkent. E húsz év alatt a tartomány pozitív migrációs mérlege mindössze 59 ezer fö volt, ${ }^{12}$ így ebben az időszakban a Vajdaság népességgyarapodása elsősorban a természetes szaporodásnak volt köszönhető. Sőt, 1981 és 1991 között a Vajdaság migrációs mérlege már negatívba fordult (1. ábra).

A Vajdaságot érintő nemzetközi migráció 1948 után minimálisra csökkent: Jugoszlávia és Magyarország között - a két ország feszült viszonya miatt - a határ „vasfüggönnyé” vált. Az észak-déli, határt átlépő vándorlások a szocializmus időszakában csak az 1956-os magyarországi események kapcsán jelentek meg, amikor a Vajdaság a magyar menekültek tranzit- (kevés esetben cél-) állomásává vált (Tóth 2001).

Sokkal jelentősebb volt az 1960-as évek közepétől - a nyugat-európai munkaerőigény és vendégmunkásprogramok, valamint Jugoszlávia relatív „,nyitottságának" hatására - kibontakozó, gazdasági indíttatású külföldi munkavállalás volumene. 1964-ben még csak 100 ezer jugoszláv állampolgár élt külföldön, ami 1971-re 750 ezerre, majd 1973-ra 1,1 millió före nőtt. A vendégmunkások többsége Nyugat-Európában, azon belül elsősorban a Német Szövetségi Köztársaságban dolgozott. Az olajválságot követően számuk valamelyest csökkent, így 1981-ben már csak 875 ezer vendégmunkást regisztráltak (Gábrity Molnár 2001). ${ }^{13}$ A Vajdaságból 1965-1970 között több mint 60 ezer fó vállalt munkát külföldön, akik között a magyarok felülreprezentáltak voltak (27,5\%) (Bukurov 1977). Az 1981-es népszámlálás időpontjában a külföldön munkavállalási céllal

1. ábra: A Vajdaság migrációs szaldójának alakulása (1941-1991) Migration balance in Vojvodina (1941-1991)

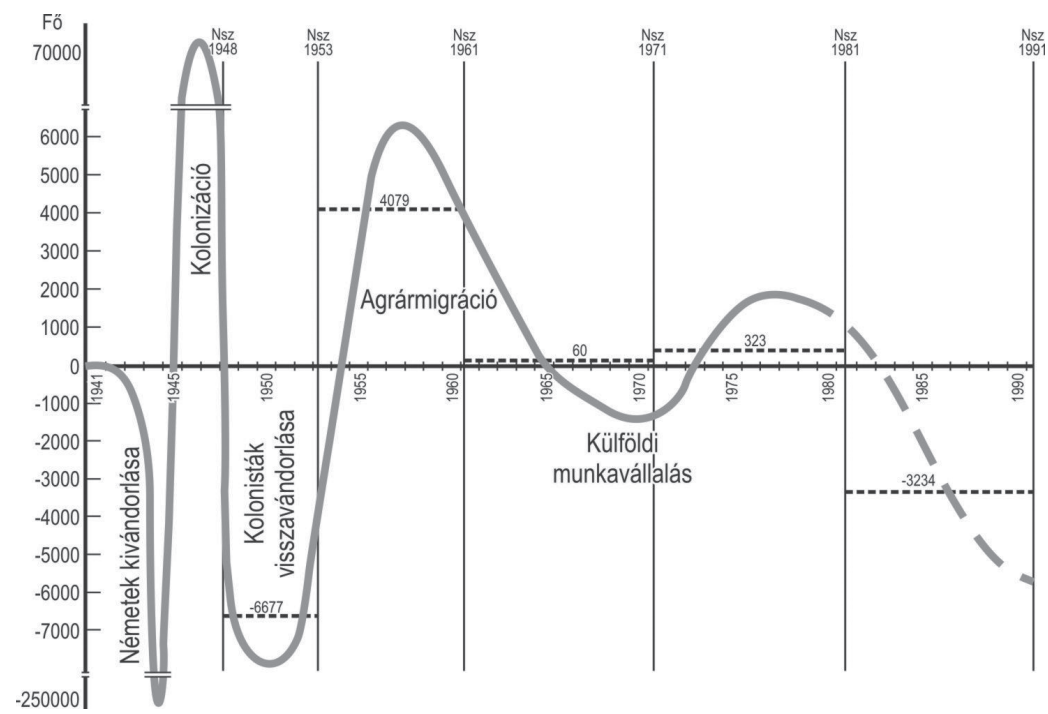

Forrás: Đurđev 1995, 58, valamint Mirnics 2001 adatai alapján saját számítások. 
tartózkodók száma 48 ezer fó volt, míg 1991-ben már csak 34 ezer vajdasági származású vendégmunkást írtak össze (Gábrity Molnár 2001). ${ }^{14}$ A külföldön munkát keresők nagy része - csakúgy mint a 20. század első felének kivándorlói - a Bánság fejletlenebb, déli részeiből indultak útnak (Kocsis 1985). A vendégmunka szelektivitását az is jelzi, hogy nem a legszegényebbek kerekedtek fel, hanem a középrétegekhez tartozó családok. A külföldi munkavállalás - legalábbis a kezdeti időszakban - transznacionális, két helyszínes struktúrát mutatott; a Német Szövetségi Köztársaságban dolgozó jugoszláv vendégmunkás családok 75 százalékában a gyerekek otthon maradtak, közeli hozzátartozók, rokonok nevelték őket. A családtagok a vendégmunkáslétet nem tekintették véglegesnek, a hazatérést tervezték. A kilencvenes években a Jugoszlávia széteséséhez vezető háborúk elől menekülők közül azért választották sokan Németországot, mert támaszkodhattak az ott dolgozó, élő vendégmunkás rokonok, ismerősök támogatására, tehát a kapcsolati háló védelmére (Goeke 2007, 121-158.).

Az 1948-1991 közötti időszakot összességében jelentős, ellentétes irányú, de az idő előrehaladtával egyre mérséklődő migrációs hullámok jellemezték (1. ábra). A vándorlási irányok egyértelműen követték a fejlettségi különbségeket: a bevándorlás a dél $\rightarrow$ északi, míg a kivándorlás a kelet $\rightarrow$ nyugati útvonalat. Ezen irányok alól csak a szocialista iparosítással felfejlesztett közép-szerbiai régió (fóként Belgrád) jelentett kivételt, amely a vajdasági népesség egy részét vonzotta (észak $\rightarrow$ dél).

\section{Az 1991 utáni migrációs folyamatok}

\section{A Vajdaságot érintő vándorlások}

A jugoszláv polgárháború kitörésével gyökeresen megváltoztak a korábbi viszonyok: felbomlott az addigi Jugoszlávia mint állami keret, a háború hatására menekültek tömege hagyta el szülőföldjét. A polgárháború időszaka alatt (1991-1995) több menekülthullám érintette Szerbiát és azon belül a Vajdaságot.

Az első menekülthullám 1991-ben Szlovéniából indult, majd 1991 nyarától Horvátországból (főként Nyugat-Szlavóniából), 1992 áprilisától pedig BoszniaHercegovinából. A menekültek száma csak 1993-ban csökkent, ami a harcok csillapuló intenzitásának és a jugoszláv gazdasági válságnak (hiperinflációs korszak) volt köszönhető (Gábrity Molnár 2001). 1995-ben a horvátországi Krajina területének horvát visszafoglalása, majd 1996-ban a daytoni békekonferencia határozatainak végrehajtása újabb menekülthullámokat indított Kis-Jugoszlávia felé. 1996 közepén a menekültek száma Szerbiában - az ENSZ Menekültügyi Főbiztossága (UNHCR) adatai alapján - elérte a 618 ezer főt, ebből a Vajdaságba érkezett 258 ezer fö (az összes menekült 42\%-a). 1997 végén és 1998 elején is megfigyelhető volt egy nagyobb, többségében a Vajdaságba irányuló szerb me- 


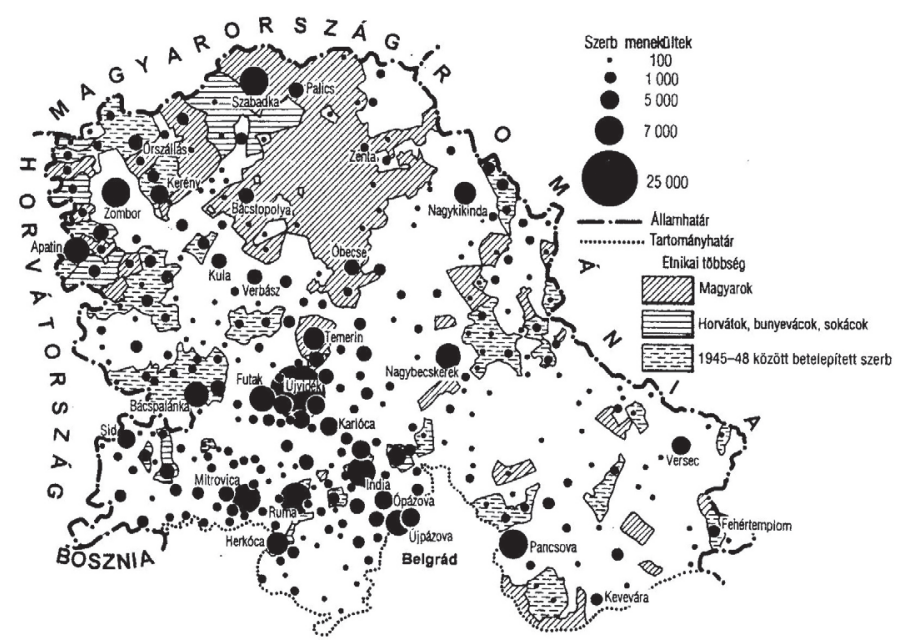

Forrás: Kocsis, Kicošev 1998, 69.

nekülthullám, melynek eredményeként a végérvényesen horvát fennhatóság alá került baranyai, kelet-szlavóniai és nyugat-szerémségi területekről - az UNHCR becslései szerint - 50 ezren települtek, menekültek át Jugoszláviába (Kocsis, Kicošev 1998). A menekültek visszatelepedése nem volt számottevő: 1998 végéig - a visszatérőkre váró bizonytalan anyagi körülmények és a sokszor ellenséges hivatali és szomszédsági környezet miatt - mindössze 26 ezren tértek vissza Horvátországba és 21 ezren Boszniába (Vandeburie 2011).

Az 1996-ban regisztrált negyedmillió menekült 94\%-a szerb volt, alapvetően tehát etnikai alapú kényszermigrációról beszélhetünk. A vázolt politikai-katonai események (pl. harci cselekmények, megtorlástól való félelem, etnikai tisztogatások) eredményeként a menekültek túlnyomó része Horvátországból (54\%) és Bosznia-Hercegovinából (37,8\%) érkezett. ${ }^{15}$ Említésre méltó, hogy - az etnikai feszültségek erősödése miatt - már ekkor megjelentek a koszovói szerb belső menekültek (Kocsis, Kicošev 1998). A menekültek földrajzi elhelyezkedése rendkívül egyenlötlen volt a Vajdaságban (2. ábra): betelepedésüket elsősorban a célterület gazdasági fejlettsége és a kapcsolati háló határozta meg; éppen ezért háromnegyedük Délnyugat-Bácskába és a Szerémségbe települt, főként az 1945-1948 között beköltözött rokonaik, ismerőseik településeire, ${ }^{16}$ míg a dél-bánsági - hagyományosan népességkibocsátó - határ menti, elnéptelenedett falvak nem bizonyultak vonzó lakóhelynek. Jelentős célállomást jelentettek a polgárháború során a Vajdaságból önként elköltözött, illetve elüzött szerémségi, bácskai horvátok lakhelyei és a kedvező életkörülményeket kínáló városok (pl. 25 ezer fó érkezett Újvidékre, ${ }^{17}$ 6-8 ezer fő Rumára, Zomborba, Pancsovára, Indiába, Mitrovicára). A Tisza-vidéki magyar etnikai tömb területére viszonylag kisszámú, 6 ezer főnyi szerb költözött. 
A kedvező forgalmi fekvésű, magyar többségű városokban és urbanizált térségekben viszont számottevő szerb menekült talált új otthonra (pl. Szabadka 6401 fö, Temerin 3444 fö) (Kocsis, Kicošev 1998).

A Szerbiába érkezett nagyobb menekülthullámok közül az utolsó az 1999-2000-es koszovói. Ekkor - a Szerb Menekültügyi Biztosság adatai szerint (www.kirs.gov.rs) - mintegy 190 ezer fó érkezett Jugoszláviába (majd 2010-ig további 20 ezer fó hagyta el Koszovót), ${ }^{18}$ arról azonban nincs adatunk, hogy mekkora hányaduk települt a Vajdaságba. A koszovói menekültek egy része számára a Vajdaság (és Magyarország) csak tranzitállomás, végső céljuk Nyugat-Európa (Kincses, Takács 2010). A 2000-es évek eleje óta a Szerbiában regisztrált menekültek száma - az állampolgárság megszerzése, a kivándorlás, valamint a hazatérés ${ }^{19}$ miatt - folyamatosan csökken, így 2012 januárjában számuk már csak 70 ezer fö. Ugyanakkor a Koszovóból érkező belső menekültek száma eléri a 228 ezer föt (www.unhcr.org), akiknek a háromnegyede szerb, tizede roma (Migration profile... 2010).

A délszláv háborúknak számottevő hatása volt a kivándorlásra is. Már 1991től tömegesen menekültek külföldre a katonai behívó, a háborús légkör, a diktatórikus rendszer, a gazdasági nehézségek elől. Az országos szinten több százezres $^{20}$ külföldre távozó tömegben felülreprezentáltak voltak a fiatalok, az értelmiségiek és az etnikai kisebbségek (Gábrity Molnár 2001; Sebők 2004). A jelentős kivándorlás ellenére a Vajdaság migrációs szaldója pozitív maradt (Penev 2006), lakossága gyarapodott, ugyanakkor jelentős népességcsere zajlott le. Ezt a folyamatot leginkább az „etnikai csere” fogalmával jellemezhetjük. 1991 és 2001 között a Vajdaságban legalább 300 ezer szerb telepedett be, amivel szemben a

3. ábra: A népességszám és az etnikai összetétel változásai a Vajdaságban (1880-2011) Changes of the population and its ethnic composition in Vojvodina (1880-2001)

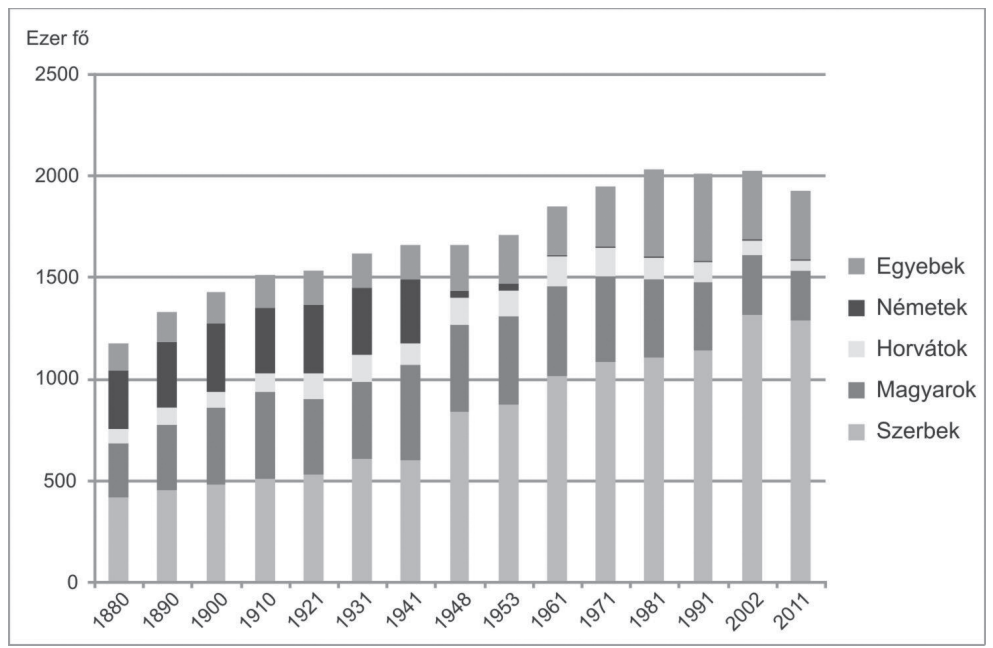

Megjegyzés: az ábrán 1941-ig a népszámlálások anyanyelvi, utána nemzetiségi adatai szerepelnek. 
nemzetiségek kivándorlása, lélekszámának csökkenése áll (3. ábra). A horvátok migrációs vesztesége mintegy 30-40 ezer fö (Kocsis, Kicošev 1998), míg a külföldre távozó magyarok számáról 30 és 50 ezer fö között mozognak a becslések. ${ }^{21}$

Az elmúlt tíz év migrációjára már nem a menekülések sorozata, hanem a szabad - elsősorban gazdasági, tanulmányi, karriercélú - migráció jellemző. A Vajdaság lakosságszáma 2002 és 2011 között 100 ezer fővel csökkent, így - részletes adatok hiányában - feltételezhetjük, hogy a negatív természetes szaporodás mellett a migrációs szaldó is negatív. ${ }^{22}$ A népességszám csökkenésében azonban jelentős területi különbségek mutatkoznak: Újvidék és agglomerációjának bevándorlás által generált népességnövekedésével szemben Észak-Bácska, valamint a Bánság határ menti részeinek jelentős népességcsökkenése áll (First results... 2011). ${ }^{23}$

Az elmúlt 20 év vajdasági vándorlásait tehát kétirányú mozgás jellemezte. Egyrészt a számottevő horvátországi, boszniai, koszovói menekülthullámok eredményeképpen több százezer szerb - a Vajdaság jelenlegi népességének mintegy 15\%-a - érkezett a tartományba; fóként Újvidékre és tágabb agglomerációjába. Ugyanakkor - elsősorban az ezredfordulóig tartó időszakban - politikai, gazdasági, biztonsági okokból szintén százezres nagyságrendben távoztak külföldre a tartományból, míg az elmúlt tíz évre egyértelműen az önkéntes, elsősorban gazdasági indíttatású, a korábbi időszakhoz képest kisebb volumenü emigráció a jellemző.

\section{A Szerbiából (Vajdaságból) Magyarországra irányuló migráció a rendszerváltás óta}

A Szerbiából - akárcsak a többi szomszédos országból - Magyarországra irányuló vándorlás a nemzetközi migráció speciális formája. Mivel az áttelepülők döntő többsége magyar, ezért több szerző (pl. Gödri, Tóth 2005; Gödri 2010a; Juhász 1994) a vándorlás e formáját a belföldi és a nemzetközi migráció közé teszi, hiszen a nyelvi, kulturális azonosság jelentősen csökkenti a migráció és integráció költségeit. A nemzeti alapú érzelmi kötődések, az anyaország kulturális vonzása szintén jelentős szerepet játszik e migrációban.

A szocializmus időszakában a Magyarországot érintő nemzetközi migrációt végig minimális szinten igyekeztek tartani. Ez a helyzet 1988-ban változott csak meg, amikor romániai menekültek és bevándorlók tömege érkezett az országba. 1988 óta a Magyarországra érkező bevándorlók többsége román állampolgár - elsősorban erdélyi magyar -, míg a menekültek többsége a volt jugoszláv tagköztársaságokból került ki (Dövényi 2006).

A volt Jugoszláviából elsősorban 1991-1992-ben, a horvátországi és a boszniai háborúk idején érkeztek nagyobb számban menekültek (e két évben 63 ezer fö). A polgárháború későbbi időszakában, a koszovói válság és NATO-bombázások idején számottevően kevesebben, évente 2-5 ezren menekültek Magyarországra (Tóth 2001). Összességében 1991 és 1999 között mintegy 85 ezer menekült 
érkezett Magyarországra a volt Jugoszláviából, többségük bosnyák, magyar és horvát nemzetiségű volt (Klenner 2007, Tóth 2001). A helyzet normalizálódása után nagyobbrészt visszatértek a szülőföldjükre; a legtovább a bosnyákok maradtak az országban (Dövényi 2006). A menekültek egy része nem tért haza, hanem harmadik országba távozott, a magyar nemzetiségűek jelentős hányada Magyarországon maradt és magyar állampolgárságot szerzett (Dövényi 2006; Juhász 1994; Klenner 2007). A volt Jugoszláviából érkező menekültek száma a 2000-

1. táblázat: A Szerbiából/Jugoszláviából Magyarországra érkező menekültek,

a Magyarországra bevándorló, a Magyarországon tartózkodó és a magyar állampolgárságot megszerző szerb/jugoszláv állampolgárok (1991-2012)

Refugees from Serbia/Yugoslavia to Hungary, Serbian/Yugoslavian citizens migrating to Hungary, residing in Hungary and acquiring Hungarian citizenship (1991-2012)

\begin{tabular}{|c|c|c|c|c|c|c|c|c|}
\hline 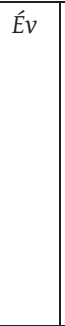 & $\begin{array}{c}\text { Menekültek } \\
\text { száma, fó }\end{array}$ & $\begin{array}{c}\text { Az összes } \\
\text { menekült } \\
\text { \%-ában }\end{array}$ & $\begin{array}{l}\text { Magyar- } \\
\text { országra } \\
\text { bevándorló } \\
\text { szerb } \\
\text { állampol- } \\
\text { gárok, fó }\end{array}$ & $\begin{array}{c}\text { Az összes } \\
\text { bevándorló } \\
\text { \%-ában }\end{array}$ & $\begin{array}{c}\text { Magyar- } \\
\text { országon } \\
\text { tartózkodó } \\
\text { szerb } \\
\text { állampol- } \\
\text { gárok } \\
\text { (január 1- } \\
\text { jén), fó }\end{array}$ & $\begin{array}{c}\text { Az összes } \\
\text { külföldi } \\
\text { állampol- } \\
\text { gár \%-ában }\end{array}$ & $\begin{array}{c}\text { Magyar } \\
\text { állam- } \\
\text { polgárságot } \\
\text { szerzőszerb } \\
\text { állam- } \\
\text { polgárok, fó }\end{array}$ & $\begin{array}{c}\text { Az összes } \\
\text { magyar } \\
\text { állam- } \\
\text { polgárságot } \\
\text { szerzö\%- } \\
\text { ában }\end{array}$ \\
\hline 1991 & $48485^{*}$ & 90,9 & .. &.. &.. & .. &.. &.. \\
\hline 1992 & $15021^{*}$ & 92,7 &.. & .. &.. & .. &.. &.. \\
\hline 1993 & $4593 *$ & 85,6 & 5060 & 30,9 & .. & .. & 223 & 2,5 \\
\hline 1994 & $2386^{*}$ & 72,9 & 2379 & 18,7 &.. &.. & 655 & 6,9 \\
\hline 1995 & $5046^{*}$ & 85,4 & 1451 & 10,4 & 15297 & 11,1 & 885 & 8,3 \\
\hline 1996 & $559^{*}$ & 44,4 & 689 & 5,0 & 16173 & 11,6 & 1233 & 12,4 \\
\hline 1997 & $329 *$ & 15,6 & 742 & 5,6 & 15449 & 10,8 & 1725 & 17,0 \\
\hline 1998 & $3333^{*}$ & 46,8 & 1490 & 9,3 & 14250 & 9,6 & 990 & 15,2 \\
\hline 1999 & $5111^{*}$ & 44,4 & 2490 & 12,4 & 15223 & 10,1 & 1103 & 15,7 \\
\hline 2000 & 692 & 8,9 & 1777 & 8,8 & 15571 & 10,2 & 1079 & 19,8 \\
\hline 2001 & 214 & 2,2 & 1028 & 5,1 & 12664 & 11,5 & 1254 & 14,6 \\
\hline 2002 & 97 & 1,5 & 437 & 2,4 & 11975 & 10,3 & 470 & 14,0 \\
\hline 2003 & 112 & 4,7 & 709 & 3,7 & 11693 & 10,1 & 343 & 6,5 \\
\hline 2004 & 180 & 11,3 & 1586 & 7,2 & 12367 & 9,5 & 533 & 9,8 \\
\hline 2005 & 243 & 15,1 & 1096 & 4,3 & 13643 & 9,6 & 949 & 9,6 \\
\hline 2006 & 384 & 18,1 & 2446 & 10,4 & 12111 & 7,8 & 357 & 5,8 \\
\hline 2007 & 911 & 26,6 & 4393 & 19,4 & 12638 & 7,6 & 757 & 9,0 \\
\hline 2008 & 327 & 10,5 & 4124 & 11,6 & 17186 & 9,8 & 758 & 9,4 \\
\hline 2009 & 536 & 11,5 & 1209 & 4,7 & 17015 & 9,2 & 672 & 11,6 \\
\hline 2010 & 446 & 21,2 & 998 & 4,2 & 17197 & 8,7 & 721 & 11,8 \\
\hline 2011 & 27 & 1,6 & 870 & 3,9 & 16301 & 7,9 & 1678 & 8,2 \\
\hline 2012 & 8 & 0,4 & .. &.. & 13226 & 6,4 &.. &.. \\
\hline
\end{tabular}

*Volt jugoszláv állampolgárok; ..=nincs adat. A menekültek száma 2008-tól a koszovói állampolgárok nélkül. Forrás: Demográfiai évkönyvek, Tóth 2001. 
es évek első felében már csak pár száz főtt tett ki, de 2007-től a koszovói helyzet kiéleződésével átmenetileg ismét nőtt a - közvélekedés szerint többségében koszovói cigány nemzetiségü - szerb állampolgárok száma a menekültek körében (1. táblázat).

A menekültek mellett a másik fö csoportot a bevándorló népesség alkotja (vö. Dövényi 2006; Hárs 2009). ${ }^{24}$ A vizsgált időszakban a legálisan Magyarországon tartózkodó külföldiek 50-80\%-a a szomszédos államokból érkezett (többségük román állampolgár volt), akik nagyrészt - a 2001-es népszámlálás szerint 81\%-ban - magyar anyanyelvüek voltak. A magyar állampolgárságot megszerzők között a szomszédos országok állampolgárai 80-90\% között részesednek (Dövényi 2006; Gödri 2010b). Mindez jól mutatja, hogy Magyarország elsősorban a szomszéd országok magyar lakosságát vonzza.

A Magyarországon tartózkodó szerb állampolgárok száma jóval kisebb ingadozást mutat, mint a menekülteké (1. táblázat). Az 1990-es években még mintegy 15 ezer főnyi szerb állampolgár élt Magyarországon, számuk - a 2000 és 2001 közötti adatrevízió miatt - a 2000-es évek első felére 12-13 ezer főre csökkent. 2007 és 2009 között újabb bevándorlási hullámot ${ }^{25}$ regisztrált a Bevándorlási és Állampolgársági Hivatal, aminek hatására számuk és arányuk megnőtt. Az átmeneti növekedés után 2012. január 1-én számuk már csak 13,2 ezer fő volt. A visszaesés mögött valószínűleg két tényező húzódik meg. Egyrészt a gazdasági válság kibontakozásával, Magyarország különösen rossz gazdasági helyzetével jelentősen veszített vonzerejéből. Ez nemcsak a bevándorlás csökkenéséből, hanem a ki- és továbbvándorlás növekedéséből is látszik, ami Magyarország tranzitországszerepére is rávilágít. Másrészt a 2010-ben módosított állampolgársági törvénynek ${ }^{26}$ köszönhetően 2011-től számottevően nőtt a magyar állampolgárok száma, ami a bevándorló státuszból való kikerülést is jelenti.

1990 óta közel 18 ezer szerb állampolgár szerezte meg a magyar állampolgárságot, emellett 2012. január 1-jén 13226 szerb állampolgár tartózkodott Magyarországon, így összességében - csak a hivatalos adatokat figyelembe véve - az elmúlt két évtizedben több mint 30 ezer szerb/jugoszláv állampolgár települt át Magyarországra. A '90-es évek első felében az áttelepült szerb/jugoszláv állampolgárok háromnegyede, míg a 2000-es években már legalább 90\%-a magyar volt (Gödri, Tóth 2005; Tóth 2001). Az állampolgárságot szerzők körében még ennél is magasabb, mintegy 97\% a magyar anyanyelvűek aránya (Kincses, Takács 2010).

2008-ban a Magyarországra áttelepült szerb állampolgárok 88\%-a a Vajdaságból (Kincses, Takács 2010), azon belül elsősorban a határhoz közeli, magyarok által nagyobb arányban lakott vidékekről származott. A Magyarországra vándorlásban leginkább érintett szerbiai települések Szabadka, Zenta és Újvidék, azaz a legnagyobb magyar közösségeknek otthont adó települések voltak (4. ábra). A Vajdaságon kívüli forrásterületek közül a legfontosabb Belgrád, azonban Koszovóból is egyre többen érkeztek Magyarországra (Kincses, Takács 2010).

A szerbiai migránsok magyarországi elhelyezkedése hasonló - bár kisebb mértékű - koncentrációról árulkodik. Az áttelepült szerb állampolgárok legin- 
4. ábra: A Magyarországon élő szerb állampolgárok az elvándorlás települése szerint (fö, 2008) Serbian citizens living in Hungary, by their former place of residence (2008)

Forrás: Kincses, Takács 2010, 191.

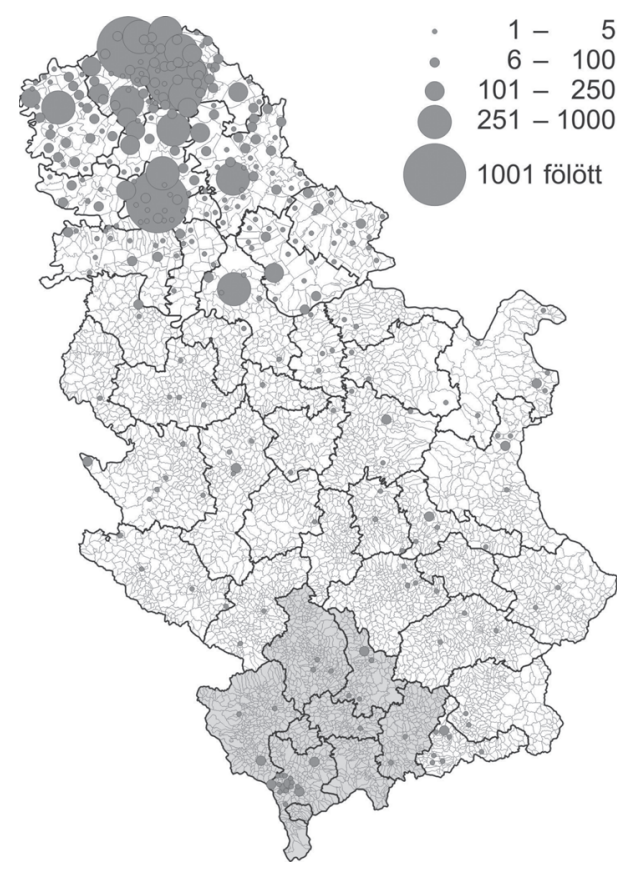

kább a szerb-magyar határ mentén, Budapesten és agglomerációjában, valamint a határ és Budapest közötti közlekedési folyosók mentén (M5, Duna vonala) telepedtek le (5. ábra). A leginkább érintett települések Szeged, Budapest és Kecskemét (Kincses, Takács 2010). Jól látható tehát, hogy a bevándorlók lakóhely-preferenciáiban a gazdasági centrumterületek mellett a származási helyhez való földrajzi közelség is fontos szerepet játszik. Fontos kiemelnünk, hogy a szomszédos országokból érkezők közül a szerb állampolgárok csoportja az egyetlen, akiknek legnagyobb áttelepült közössége nem Budapesten él. ${ }^{27}$ Ugyanakkor a Dél-Alföld és Szeged súlya egyre csökken, míg a központi régió szerepe folyamatosan nő a szerb állampolgárok letelepedési célterületeit vizsgálva (vö. Kincses 2010), ${ }^{28}$ ami a megélhetési, boldogulási szempontok előtérbe kerülését jelenti az új lakóhely megválasztásánál.

A Szerbiából Magyarországra irányuló migráció lényeges jellemzője, hogy a két ország között „erős, koncentrált áramlás valósul meg” (Kincses, Takács 2010, 193.), amely elsősorban Észak-Vajdaságból Csongrád és Bács-Kiskun megyékbe irányul. Azon migránsok, akik a közös határ magyar oldalára telepedtek, közel 80\%-ban a határhoz közelről érkeztek, míg a Vajdaságon kívülről származó migránsok inkább a központi területeket részesítik előnyben (Kincses, Takács 2010).

A migránsok áttelepülést követő mozgását vizsgálva két fontosabb sajátosság tünik fel. Általánosságban a már letelepedett külföldiek további vándorlásait 
5. ábra: A Magyarországon élő szerb állampolgárok a tartózkodási településük szerint (fo, 2008) Serbian citizens living in Hungary, by place of residence (2008)

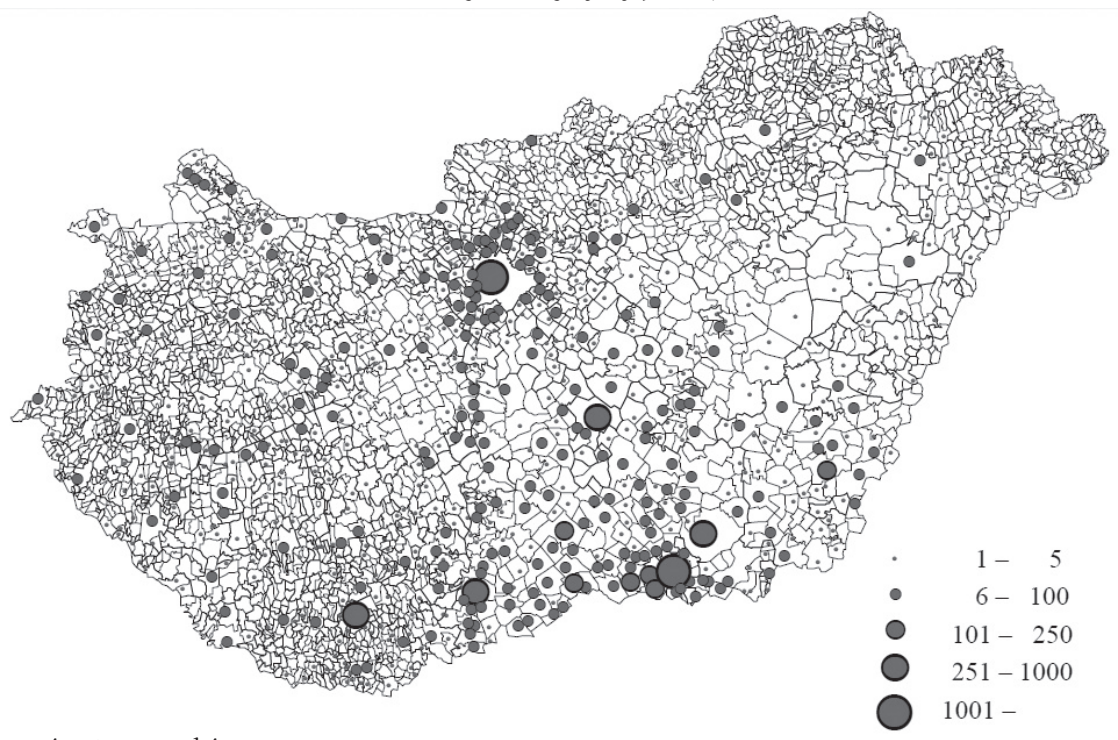

Forrás: Kincses, Takács 2010, 192.

elsősorban a kis távolságú mozgások jellemzik, azaz Magyarországon inkább kistérségeken belül mozognak, és kevésbé jellemző rájuk a centrum (Budapest) irányába továbbvándorlás (Rédei 2012). Viszont a szerb állampolgárok esetében - a román és ukrán állampolgárokhoz hasonlóan - a Magyarországon belüli mobilitásnál sokkal nagyobb volumenű a cirkulációs vándorlás, tehát a két (néha több) ország közötti különböző típusú mozgások (pl. ingázás a határon át) (Illés 2012).

A napjainkban Magyarországon élő szerb állampolgárok egyes jellemzői jelentősen eltérnek a 20 évvel korábbitól, elsősorban annak köszönhetően, hogy a migránsok köre nagyrészt kicserélődött (a vissza- és továbbvándorlások, az állampolgárság megszerzése, a halálozás okán). A kezdetben a háborús körülmények miatt kialakuló nagy férfitöbblet valamelyest kiegyenlítödött, de még napjainkban is több férfi érkezik, mint nő (Demográfiai évkönyv 2012). Korcsoportok szerint vizsgálva megállapítható, hogy a Magyarországon tartózkodó szerb állampolgárok egyre idősebbek: ${ }^{29}$ míg 1995-ben még 73\%-uk volt 40 év alatti, addig ez az érték 2003-ra 66\%-ra, 2012-re pedig 44\%-ra csökkent (Demográfiai évkönyv 2012). Ez azt mutatja, hogy míg kezdetben főként a fiatal férfiak vándoroltak be, addig a későbbiekben a családok (Gödri, Tóth 2005); 2006 és 2009 között jelentős volt az idős bevándorlók részesedése, akik többnyire az 1990-es években áttelepedett gyerekeik után jönnek az országba (szekunder migráció). Utóbbi jelenség némileg késve bontakozott ki, hiszen Romániából és Ukrajnából már az ezredfordulón megfigyelhető volt a szekunder migráció.

A magyarországi tartózkodás célja szerint is jelentős elmozdulás figyelhető meg: míg 2007-ig a bevándorlási kérelmeken megjelölt „hivatalos” tartózkodási cél 
elsődlegesen a bevándorlás és a letelepedés volt, addig 2007 után egyre fontosabb szerepet játszik a családegyesítés és a tanulmányi célú migráció, de természetesen jelen van a munka és keresőtevékenység miatti, valamint karriercélú tartózkodás is (Demográfiai évkönyv 2012; Gábrity Molnár, Takács 2012)..$^{30}$ Az idősek mellett leginkább a továbbtanulási céllal érkező diákok száma nő (Erőss, Filep, Rácz, Tátrai, Váradi, Wastl-Walter 2011): a Magyarországon tanuló szerb állampolgárok száma a NATO-bombázások óta nem volt olyan magas, mint napjainkban. Összességében egyre jelentősebb az ideiglenes tartózkodási céllal (pl. munka, tanulás) érkezők aránya, amely - mint korábbi vizsgálatok ezt kimutatták - akár a végleges letelepedéshez vezető út első lépése lehet (Gödri 2010a; Gödri, Tóth 2005).

\section{Következtetések}

Az elmúlt évszázad Vajdaságba, illetve onnan Magyarország mai területére irányuló migrációs folyamatait áttekintve levonható néhány fontos következtetés. A legfontosabb, hogy a vándorlások szempontjából alapvetően kétféle időszakot határolhatunk le: egyrészt a háborús időszakokat, amikor az államhatárok változása miatt tömeges (kényszer)migráció bontakozott ki. Ezen időszakokban a fó cél a biztonság elérése volt, amelyhez természetesen gyakorta kapcsolódtak egyéb motivációk is, hiszen például a hatalmi viszonyok változása miatt a korábbi gazdasági viszonyok és egyes (pl. nyelvietnikai) csoportok gazdasági helyzete gyökereiben megváltoztak. A migráció iránya ekkor nem feltétlenül követte a fejlettségi különbségeket, hiszen a cél a biztonságos helyre jutás volt, ami általában egyet jelentett az anyaországba (illetve saját etnikai közegbe) kerüléssel.

Ugyanakkor békeidőben, amikor a vándorlási folyamatok jellemzően önkéntesnek tekinthetők, a migráció gazdasági meghatározottsága került előtérbe. Ezen időszakokban a fö migrációs irányok követték a fejletlen $\rightarrow$ fejlett (vagy periféria $\rightarrow$ centrum) útvonalat, amelyek az elmúlt száz évben csak keveset változtak. $\mathrm{E}$ jelenség esetünkben beágyazható a globális vándorlási rendszerbe is, hiszen a vizsgált migráció egyértelműen része a kelet $\rightarrow$ nyugat (pl. vendégmunkások), illetve még inkább a dél $\rightarrow$ észak (Vajdaság $\rightarrow$ Magyarország; telepesek, menekültek $\rightarrow$ Vajdaság) irányú vándorlásoknak, de talán ide tartozik a harmadik dimenzió is: fentről le, azaz a hegyekből az alföldre. ${ }^{31}$ Utóbbi jelenséget - amely elsősorban a világháborúk utáni vajdasági telepítésekre és részben a menekültekre vonatkozik - szintén jelentős fejlettségbeli különbségek idézték elő, hiszen a forrásterületeket vizsgálva feltűnő a periférikus hegyvidékek kibocsátó szerepe és a fejlettebb régiókból érkezett telepesek (pl. a szlovénok) gyors hazatérése (részletesen lásd Đurđev 1995).

Annak ellenére, hogy a vizsgált vándorlások illeszkednek a globális migrációs rendszerekbe, nagyon fontos sajátosságuk, hogy földrajzilag többnyire közeli lokalitások között valósulnak meg. Ez különösen igaz a Vajdaságból Magyarországra irányuló migrációra, hiszen Kincses és Takács (2010) vizsgálatai is bizonyították, 
hogy gyakran csak a határ magyar oldaláig mentek az áttelepülők. Ebből a szempontból nézve a Szegedre irányuló migráció gyakorlatilag a város és (a tőle államhatárral elválasztott) vonzáskörzete között lezajló, az 1918 előtti és 1941-1944 közötti természetes kapcsolatokat helyreállító mozgás, ami akár transznacionális térben zajló migrációként is értelmezhető (lásd Feischmidt, Zakariás 2010, 159.). Összességében egyetértünk Kincsessel $(2010,211$.$) abban, hogy „az új lakóhely vá-$ lasztásában a gazdasági centrumterületek mellett a szomszédos fekvésű - ez esetben periférikus - térségek is fontos szerepet játszanak, azaz a migrációs hajlandóság a gazdasági különbségekkel egyenes, míg a távolsággal - legyen az topográfiai, vagy kulturális - fordított arányban áll”.

Az idézett kulturális távolság pedig elvezet minket a vizsgált migráció egyik legfontosabb specifikumához, az etnikai tényező vándorlásban betöltött szerepéhez. Értelmezésünkben mind a határváltozások generálta kényszermigrációk, mind a szerb menekülteknek a szerb nemzetállamba települése, mind a vajdasági magyarok Magyarországra vándorlása etnikai migrációnak számítanak. Ugyanakkor hangsúlyoznunk kell, hogy az általunk vizsgált etnikai migrációban - térben és időben eltérő mértékü - szerepe van az etnikai taszító tényezőknek (pl. etnikai konfliktus, diszkrimináció), csakúgy mint a gazdasági-fejlettségi különbségeknek; mindössze eme tényezők migrációs folyamatokban játszott, egymáshoz viszonyított fontossága, súlya változott meg az elmúlt húsz esztendő folyamán.

\section{Jegyzetek}

1 A gazdasági fejlődéssel párhuzamosan, a közegészségügyi helyzet javulása eredményeként a délvidéki megyékben (Bács-Bodrog, Torontál, Szerém) is jelentősen csökkent a halálozási arányszám és nőtt a természetes szaporodás, melynek értéke (a három megye átlagában) 1880-1910 között elérte az évi 13,9\%o-et (1869-1880: 4,5\%, 1910-1921: 6,2\%). Ebben az időszakban belföldi migráción a Magyar Birodalmon (Transleithania), tehát Magyarország és Horvát-Szlavónország együttes területén belüli, vármegyehatárokat átlépő vándorlást értjük.

3 Ezen adatsorok csak korlátozottan alkalmasak a migrációs folyamatok bemutatására: nem tájékoztatnak - többek között - a vándorlás időpontjáról, valamint a több alkalommal történő lakóhely-változtatásokról sem (Beluszky 2004).

4 1900-ban a Monarchián kívül születettek aránya: Bács-Bodrog 0,2\%, Torontál 0,5\%, Szerém 1,6\%.

5 Ugyanakkor meg kell említeni, hogy a két világháború közötti vajdasági földreformból összesen 19,2 ezer (szinte kizárólag délszláv) család (kb. 100 ezer fö) részesült, akiknek fele lehetett vajdasági (Gaćeša 1968, 1972, 1975).

6 A két világháború között a Vajdaságból 47,4 ezer fó vándorolt külföldre (Bukurov 1976). Az 1921-1929 között a tengerentúlra emigrált vajdasági magyarok száma 10 ezerre volt tehető (Nyigri 1941).

7 Ebben az időszakban duzzadt 15 ezer fősre az akkor még szinte teljesen magyarlakta (Darányi) Telep Újvidék nyugati részén (Mesaroš 1981).

8 A szerb szakirodalom ugyanakkor legalább 30 ezer főben állapítja meg a magyar hatóságok által elüldözöttek számát (Kasaš 1996).

9 A kényszermigrációk és háborús veszteségek eredményeként a németek száma a Vajdaság mai területén az 1931-beli 329 ezerről 1953-ra 35 ezer főre zuhant. 
10 1948-ban ez az érték 36\% (600 ezer fó) volt (Mirnics 2001).

11 Közép-Szerbiának nevezzük a mai Szerbia Vajdaság és Koszovó-Metóhia (valójában a független Koszovó Köztársaság) nélküli részét.

12 Azonban Közép-Szerbiával és Szlovéniával szemben már ekkor veszteséges volt a népességcsere mérlege.

13 Az adatok azonban nem teljesen összehasonlíthatók, hiszen az 1981-es népszámlálás alkalmával nem regisztrálták az 1971-ben külföldön tartózkodók 31\%-át. Ők nem tértek vissza, többségük valószínűleg megszerezte új hazája állampolgárságát (Gábrity Molnár 2001).

14 A magyarok aránya a vajdasági vendégmunkásokon belül végig $25 \%$ felett maradt. A vendégmunkások számához a népszámlálások nem számították hozzá a családtagokat, akikkel együtt még 1991-ben is mintegy 50 ezer volt a vendégmunkások száma. Sebők László (2004) becslése szerint közel félszázezer vajdasági magyar élhetett a hetvenes-nyolcvanas években NyugatEurópában. Fontos megemlíteni, hogy egy részük visszatérve nem a Vajdaságban, hanem a horvát tengerparton telepedett le (Sebők 2004).

15 A 2002-es népszámlálás szerint 1991 és 2002 között Horvátországból 126,5 ezer, Bosznia-Hercegovinából 56 ezer, míg Koszovóból 11,5 ezer fó települt be a Vajdaságba (Stevanović 2007).

16 Az etnikai-kulturális hasonlóság és a kapcsolatháló migrációban játszott szerepét jól mutatja, hogy a menekültek 60\%-a rokonokhoz, barátokhoz került, és mindössze 6\%-uk élt menekülttáborokban (Kocsis, Kicošev 1998).

17 Így a fó célpontnak számító Újvidék lakossága az 1991-es 180 ezerről 2002-ben 191 ezer főre, míg 2011-re 222 ezer főre gyarapodott. Ebben az időszakban az ország legdinamikusabban gyarapodó városába, Újvidékre több betelepülő érkezett, mint Belgrádba (Marinović, Bugarin 2006).

18 Ezzel szemben Sebők (2004) 300 ezer, míg Gábrity (2001) 350 ezer koszovói menekültről tud.

19 A hazatért menekültek számáról az adatok ellentmondásosak. Vandeburie (2011) a UNHCR adataira alapozott statisztikája szerint 1996 és 2002 között Horvátországba 76,7, Bosznia-Hercegovinába 59,3 ezer fő tért vissza Szerbia és Montenegróból, viszont a Szerb Menekültügyi Biztosság 2010-ig összesen csak 130 ezer visszatérő menekültről tud (www.kirs.gov.rs).

20 Kincses és Takács (2010) 200-500 ezer, míg Sebők (2004) 350 ezer külföldre távozóról ír.

21 Kocsis (1996) 1996-ig mintegy 30 ezer Magyarországra és Nyugat-Európába költöző magyarról ír; Mirnics (2001) 1991-2001 között 35-40 ezerre becsüli a vándorlási veszteséget; míg Gábrity Molnár (2001) ugyanezen időszakra 50 ezer föt becsül.

22 A 2011-es népszámlálás szerint a külföldön tartózkodó vajdaságiak száma 46 ezer fő (First results... 2011).

23 Kincses (2010) számításai szerint csak a Magyarországra történő elvándorlás 1,5-2\%-kal csökkentette az Észak-bácskai és az Észak-bánsági körzet lakosságszámát 2001 és 2008 között.

24 A Magyarországon élö külföldi népességgel kapcsolatos definíciós problémákról és számbavételi lehetőségekről részletesen lásd Hárs 2009.

25 A növekedés feltételezhető okai Magyarország schengeni övezethez való csatlakozása és az így „lezáruló” határtól való félelem, továbbá a koszovói függetlenedés körüli feszültségek.

26 A 2010-ben módosított állampolgársági törvény alapján a határon túl élő magyarok kedvezményesen, egyszerűsített honosítási (és visszahonosítási) eljárásban szerezhetik meg a magyar állampolgárságot.

27 E jelenségben fontos szerepet játszik, hogy a '90-es években a háború elől áttelepültek jelentős része csak rövid távú magyarországi létre rendezkedett be, éppen ezért nem költözött messze a határtól.

28 2011-ben már több szerb állampolgárságú érkezett Budapestre, mint Csongrád megyébe, bár a legtöbb szerb állampolgár 2012. január 1-jén még mindig Csongrád megyében élt.

29 Viszont ha a bevándorló szerb állampolgárok korösszetételét vizsgáljuk, akkor azt láthatjuk, hogy egyre csökken a gyerekkorúak (14 év alatt) részesedése, és az elmúlt két évben minimális az idősek (60 év felett) bevándorlása is. A bevándorlók többségét a fiatalok (15-24 évesek) adják, ami tanulmányi célú migráció kiemelt jelentőségét mutatja.

30 Továbbá meglehetősen magas az „egyéb és ismeretlen” céllal Magyarországra érkezők száma. A statisztikai adatokhoz hasonló eredményre jutott Gödri és Tóth (2005) egy reprezentatív kérdőíves felmérés során. 
31 A Vajdaságba betelepülő boszniai, horvátországi montenegrói telepesek, menekültek kapcsán migráns és vajdasági magyar interjúkban gyakori a „hegyi” jelző használata.

\section{Irodalom}

A Magyar Szent Korona országainak kivándorlása és visszavándorlása 1899-1913. Magyar Statisztikai Közlemények, Új sorozat, 67., Budapest, 1918.

A. Sajti E. (1987): Délvidék 1941-1944. Kossuth Kiadó, Budapest

Beluszky P. (2004): Belső vándorlások a dualizmus korában Magyarországon. In: Hanusz Á. (szerk.): Földrajzi környezet - történeti folyamatok. Nyíregyházi Főiskola Természettudományi Főiskolai Kar Földrajz Tanszéke, Nyíregyháza, 55-77.

Brubaker, R. (1998): Migration of ethnic unmixing in the "New Europe". International Migration Review, 4., 1047-1065.

Bukurov, B. (1976): Spoljašnje migracije naroda Jugoslavije izmedju dva svetska rata. Zbornik Matice Srpske za prirodne nauke, 51., 5-31.

Bukurov, B. (1977): Etnička struktura radnika koji su na privremenom radu u inostranstvu. Zbornik radova Geografskog instituta ,Jovan Cvijić", 29., 135-156.

Demográfiai évkönyv 2011. KSH, Budapest, 2012.

Dövényi Z. (2006): A Magyarországot érintő nemzetközi vándorlás területi jellemzői. In: Tóth P. P. (szerk.): Bevándorlás Magyarországra. Lucidus Kiadó, Budapest, 121-147.

Đurđev, B. (1995): Posleratno naseljavanje Vojvodine. Matica Srpska, Novi Sad

Erőss Á., Filep B., Rácz K., Tátrai P., Váradi M. M., Wastl-Walter, D. (2011): Tanulmányi célú migráció, migráns élethelyzetek: vajdasági diákok Magyarországon. Tér és Társadalom, 4., 3-19.

Feischmidt M., Zakariás I. (2010): Migráció és etnicitás. A mobilitás formái és politikái nemzeti és transznacionális térben. In: Feischmidt M. (szerk.): Etnicitás. Különbségteremtö társadalom. Gondolat, MTA Kisebbségkutató Intézet, Budapest, 152-169.

First results of the 2011 census of population, households and dwellings in the Republic of Serbia. Statistical Office of the Republic of Serbia. Beograd, 2011. http://media.popis2011.stat.rs/2011/prvi_rezultati.pdf (Letöltés: 2012. október 29.)

Gábrity Molnár I. (2001): A jugoszláviai magyarok vándormozgalmának oka és méretei. In: Gábrity Molnár I., Mirnics Zs. (szerk.): Fészekhagyó vajdaságiak. MTT, Szabadka, 115-161.

Gábrity Molnár I., Takács Z. (2012): A kibocsátó terület - Vajdaságban élők véleményei. In: Kincses Á. (szerk.): Szerb állampolgárok Magyarországon. PrintPix, Budapest, 40-68.

Gaćeša, N. (1968): Agrarna reforma i kolonizacija u Bačkoj, 1918-1941. Matica Srpska, Novi Sad

Gaćeša, N. (1972): Agrarna reforma i kolonizacija u Banatu, 1919-1941. Institut za izučavanje istorije Vojvodine i Matica Srpska, Novi Sad

Gaćeša, N. (1975): Agrarna reforma i kolonizacija u Sremu, 1919-1941. Institut za izučavanje istorije Vojvodine i Matica Srpska, Novi Sad

Gaćeša, N. (1984): Agrarna reforma i kolonizacija u Jugoslaviji 1945-1948. Matica Srpska, Novi Sad

Goeke, P. (2007): Transnationale Migrationen. Post-jugoslawische Biografien in der Weltgesellschaft. transcript, Bielefeld

Gödri I. (2010a): Migráció a kapcsolatok hálójában. A kapcsolati tőke és a kapcsolathálók jelenléte és szerepe az ezredvégi magyarországi bevándorlásban. KSH Népességtudományi Kutatóintézet, Budapest

Gödri I. (2010b): Bevándorlás és etnicitás - összefüggések nyomában. In: Hárs Á., Tóth J. (szerk.): Változó migráció - változó környezet. MTA Etnikai-nemzeti Kisebbségkutató Intézet, Budapest, 87-124.

Gödri I., Tóth P. P. (2005): Bevándorlás és beilleszkedés. A szomszédos országokból Magyarországra irányuló bevándorlás az ezredfordulón. KSH Népességtudományi Kutatóintézet, Budapest

Hárs Á. (2009): Nemzetközi migráció a számok és a statisztika tükrében. Statisztikai Szemle, 7-8., 682-711. 
Illés S. (2012): Cirkulációs migráció és integráció. In: Kincses Á. (szerk.): Szerb állampolgárok Magyarországon. PrintPix, Budapest, 146-177.

Juhász J. (1994): A Magyarországot érintő nemzetközi vándorlás. Demográfia, 1., 32-59.

Kasaš, A. (1996): Mađari u Vojvodini 1941-1946. Filozofski Fakultet u Novom Sadu, Novi Sad

Kincses Á. (2010): A Kárpát-medence országaiból Magyarországra tartó vándorlások demográfiai és geográfiai vonatkozásai, 2001-2008. Demográfia, 2-3., 205-233.

Kincses Á., Takács Z. (2010): Szerb állampolgárok Magyarországon. Területi Statisztika, 2., 183-197.

Klenner Z. (2007): Menekültek Magyarországon a 2000-es években. Kisebbségkutatás, 4., 679-697.

Kocsis K. (1985): Migrációs folyamatok a Vajdaságban a második világháború után. Földrajzi Értesito”, 4., 431-454.

Kocsis K. (1996): Adalékok a magyarság etnikai földrajzához a mai Vajdaság területén. In: Dövényi Z. (szerk.): Tér - gazdaság - társadalom. MTA FKI, Budapest, 339-373.

Kocsis K., Kicošev, S. (1998): A menekültügy társadalmi-demográfiai aspektusai a Vajdaságban. Regio, 3., 63-74.

Marinović, I., Bugarin, R. (2006): Migracione karakteristike stanovništva Vojvodine. Zbornik Matice srpske za društvene nauke, 121., 59-67.

Mesaroš, š. (1981): Polažaj madjara u Vojvodini 1918-1929. Filozofska Fakulteta, Universitet u Novom Sadu, Novi Sad

Migration Profile of the Republic of Serbia for 2010. http://www.kirs.gov.rs/docs/mp_rs_2010e.pdf (Letöltés: 2012. november 15.)

Milošević, S. D. (1981): Izbeglice i preseljenici na teritoriji okupirane Jugoslavije 1941-1945. Beograd

Mirnić, J. (1974): Nemci u drugom svetskom radu. Novi Sad

Mirnics K. (2001): Betelepítések, kitelepítések és vándormozgalmak. In: Gábrity Molnár I., Mirnics Zs. (szerk.): Fészekhagyó vajdaságiak. MTT, Szabadka, 9-75.

Nyigri I. (1941): A visszatért Délvidék nemzetiségi képe. In: Csuka Z. (szerk.): A visszatért Délvidék. Budapest, 293-535.

Penev, G. (2006): Vojvođanske migracije tokom 1990-ih godina: više doseljenih, manje odseljenih. Zbornik Matice srpske za društvene nauke, 121., 77-84.

Rédei M. (2012): A Magyarországra irányuló nemzetközi migráció jellemzői az ezredfordulót követően. Munkaügyi Szemle, 2., 31-44.

Sebők L. (2004): A délvidéki demográfiai folyamatok - elsősorban a magyarok vonatkozásában. In: Kiss T. (szerk.): Népesedési folyamatok az ezredfordulón Erdélyben. Kriterion, RMDSZ Ügyvezető Elnökség, Kolozsvár. http://adatbank.transindex.ro/inchtm.php?akod=347 (Letöltés: 2012. november 15.)

Stark T. (2001): Háborús népességmozgás a Kárpát-medencében (1938-1948). In: Faragó T., Őri P. (szerk.): Történeti demográfiai évkönyv 2001. KSH Népességtudományi Kutatóintézet, Budapest, 389-411.

Stevanović, R. (2007): Migrantsko stanovništvo Vojvodine. In: Đurđev, B. S. (szerk.): Stanovnoštvo $i$ domaćinstva Autonomne Pokrajine Vojvodine početkom XXI veka. APV, Pokrajinski sekretarijat za demografiju, porodicu i društvenu brigu o deci, Novi Sad, 71-101.

Tilly, C. (2001): Áthelyeződött hálózatok. In: Sik E. (szerk.): A migráció szociológiája. Szociális és Családügyi Minisztérium, Budapest, 89-104.

Tóth P. P. (2001): Jugoszláviából Magyarországra. In: Gábrity Molnár I., Mirnics Zs. (szerk.): Fészekhagyó vajdaságiak. MTT, Szabadka, 251-269.

Vandeburie, J. (2011): Geografija kretanja izbeglica na Balkanu posle 1989: od zemalja porekla do odredišta. In: Penev, G. (szerk.): Migracije, krize i ratni sukobi na Balkanu s kraja 20. veka. Društvo demografa Srbije. DémoBalk, Beograd, 71-82.

www.kirs.gov.rs/docs/prez/Commissariat\%20-\%20English.zip (Letöltés: 2012. november 15.)

www.unhcr.org/pages/49e48d9f6.html (Letöltés: 2012. november 15.) 